\title{
From high stress to de-stressed - mining in changing conditions
}

\author{
P Bergström First Quantum Minerals Ltd., Finland \\ K Sahala First Quantum Minerals Ltd., Finland \\ M Hakala KMS Hakala Oy, Finland
}

\begin{abstract}
This paper aims to describe the changes in stress and rock mass conditions during 13 years of deep mining. Stoping in originally high stress environment has led to detachment and subsidence of remaining oreblocks along schistosity surfaces of the immediate wall rock, while high-stress related seismicity has moved further from the actual mining area. Also presented is history of numerical stress modelling and its correspondence to the observed rock mass behaviour. Finally, adjustments made to mine planning, production and ground monitoring are described.
\end{abstract}

\section{Introduction}

The Pyhäsalmi Mine is located in central Finland and owned by First Quantum Minerals Ltd., a Canadian-based global mining company that produces base metals, gold and platinum group elements. Pyhäsalmi Mine Oy (PMO) produces copper, zinc and pyrite concentrates, processing $1.4 \mathrm{~m} \mathrm{t}$ of massive sulphide ore annually (average grades Cu 1\%, Zn 2.5\%, S 41\%).

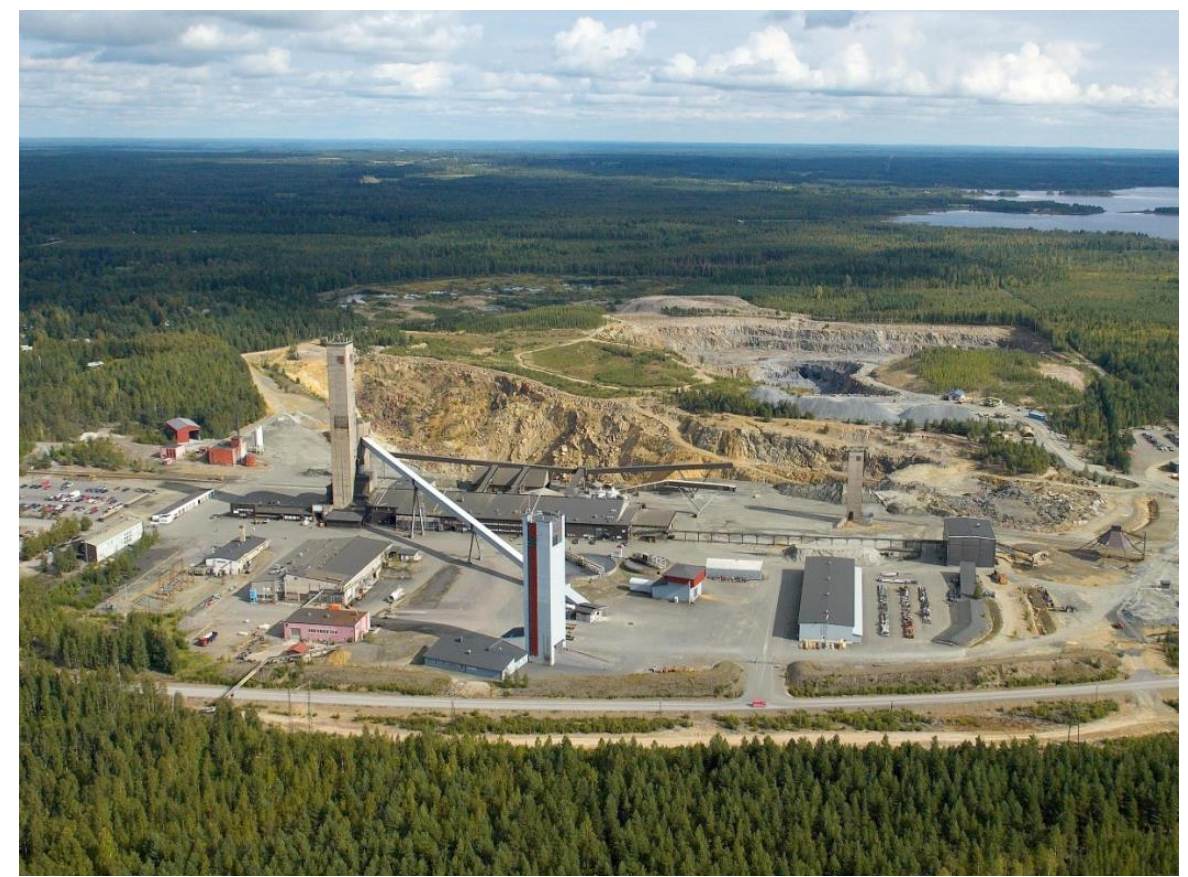

Figure 1 Aerial view of Pyhäsalmi Mine showing the main surface infrastructure

Since the 1970s, production has been solely from the underground mine. The ellipsoid-shaped deep orebody, a continuation to the previously known subvertical orebody, was found in 1996 and taken into production in 2001. New production levels, continuation of the main ramp, main level and 1,450 m deep hoisting shaft were built for the massive sulphide extraction at depth between 1,050-1,425 $\mathrm{m}$ below surface. The present reserves provide life-of-mine (LOM) until 2019.The ellipsoid-shape deep part of 
Pyhäsalmi ore is hosted by hard but fragile quartz-rich felsic volcanic rocks. The contact zone between the wall rock and massive sulphide is tectonic, sheared and sharp. The massive sulphide is homogenous and originally sparsely fractured (Figure 2). The main ore types are sphalerite and chalcopyrite-pyrite ores in the outer rims of the orebody and partly uneconomic massive pyrite in the core.

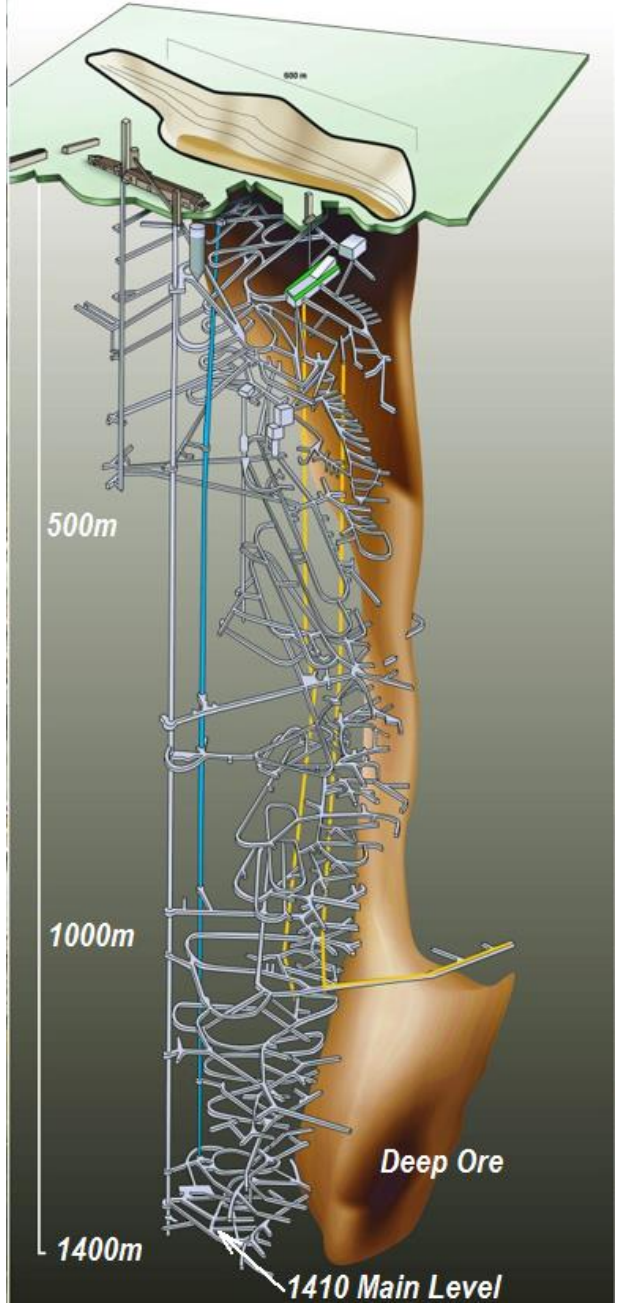

(a)

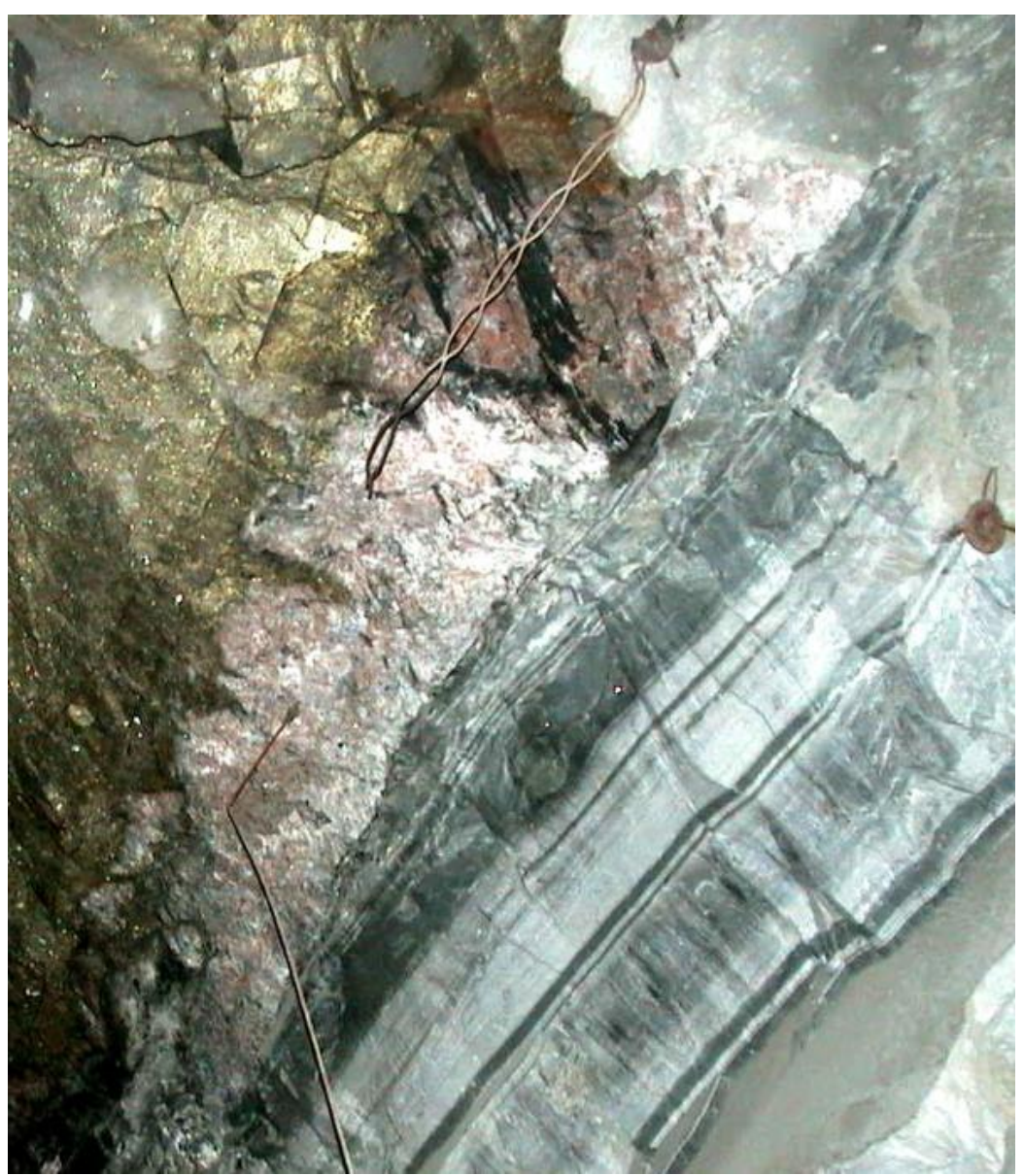

(b)

Figure 2 Model view of Pyhäsalmi Mine orebody and underground infrastructure (a); and the main rock types (b); massive sulphide ore at the upper left corner and quartz-feldspar schist at lower right (Sahala 2011)

\section{Rock mechanical conditions and mining method}

Horizontal in situ stress in Pyhäsalmi deep mine, measured prior to extraction at $-1,125$ and $-1,350$ to -1,375 levels (Ledger 1999; Mononen 2000) is relatively high (Figure 3, Table 1). In these circumstances the mining was originally designed to start from the bottom level and to be expanded simultaneously into horizontal and vertical directions in an arrowhead shape using the primary and secondary stopes. Stoping direction followed northwest-southeast trending profiles, direction of which is roughly parallel the main horizontal stress $\left(310^{\circ}\right)$ and is also perpendicular to the deep orebody trend (Figure 4). The secondary profiles were designed to be vertical pillars between the primary stopes and to yield through primary stoping stress concentration. The profile width was $15-18 \mathrm{~m}$ for the primaries and $20-25 \mathrm{~m}$ for the secondaries. Stope height of 25 or $50 \mathrm{~m}$ with sublevel was applied, and 4-6 stopes kept concurrently in production. Rockfill with consolidating hydraulic fill was planned for the primaries only; secondaries were to be rockfilled. 
Both the massive sulphide and wall rock schists are hard and relatively stiff in nature (Table 1). Primary fracturing is sparse in the massive sulphide but strong schistosity with parallel banding defines the behaviour of the wall rock.

Estimated primary horizontal stress at 1,400 m depth was $75 \mathrm{MPa}$ which was shown to be correct when new stress measurements were completed in 2013 (Hakala, personal communication, 25 April 2014).

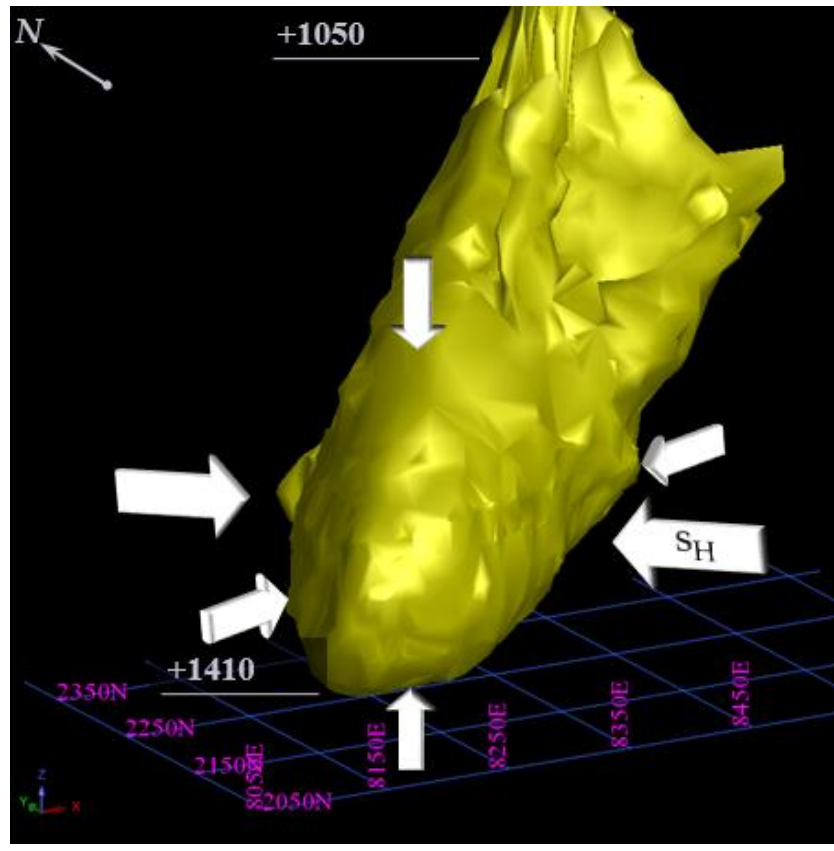

Figure 3 Main stress directions (Sahala 2011)

Table 1 Physical rock properties of the main rock types and principal in situ stresses prior to mining at Pyhäsalmi Mine (Hakala et al. 2002)

\begin{tabular}{cc}
\hline Rock properties & \\
\hline UCS (massive sulphide) & $90-120 \mathrm{MPa}$ \\
UCS (wall rock) & $200-240 \mathrm{MPa}$ \\
E (massive sulphide) & $90-140 \mathrm{GPa}$ \\
$\mathrm{E}$ (wall rock) & $60-80 \mathrm{GPa}$ \\
Poisson (massive sulphide) & $0.32-0.34$ \\
Poisson (wall rock) & $0.24-0.26$ \\
\hline Measured primary stress & \\
(1,125 m depth) & $65 \mathrm{MPa}$ \\
\hline SH $_{\text {( main horizontal) }}$ & $33 \mathrm{MPa}$ \\
$\mathrm{S}_{\mathrm{V}}$ (vertical) & $41 \mathrm{MPa}$ \\
$\mathrm{Sh}_{\mathrm{h}}$ (minor horizontal) & 1.99 \\
\hline SH $/ \mathrm{sV}^{2}$ & \\
\hline
\end{tabular}




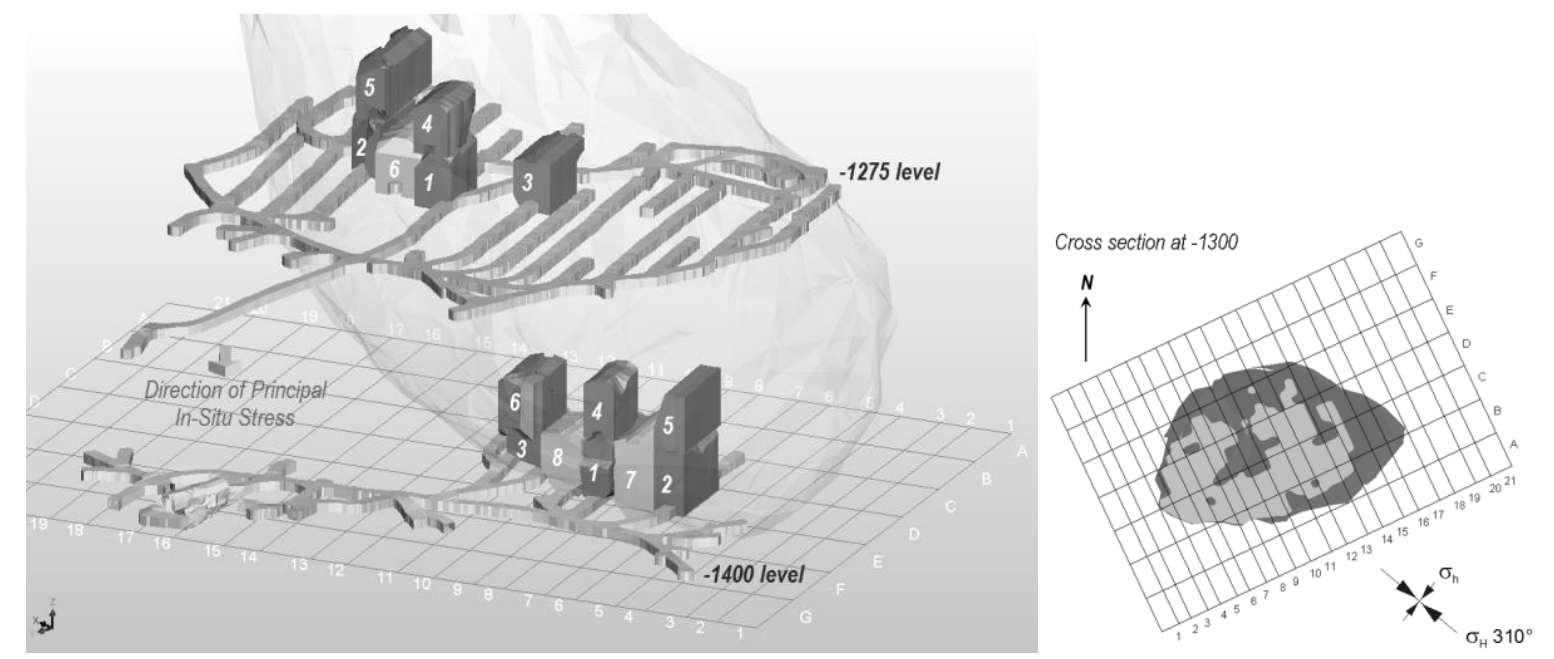

Figure 4 Schematic figure illustrating the mining grid (cross-section, right); and original scheduling with primary-secondary stopes (left), proceeding in a pyramid front. Concurrently 4-6 stopes in production are needed to meet the mill feed. This scheduling scheme was originally adopted to best fit the high stress environment

\section{Rock mass behaviour during past and present mining}

\subsection{Early rock mass response to mining}

Deep orebody extraction was started in three or four stoping areas of primaries and secondaries in the bottom, western and southern parts. The full profiles were usually mined from south to north. The first fully mined out primary profiles, which started from the bottom and reached at least the vicinity of the hangingwall contact were 2 and 4, with 6 following up fairly soon. This left 175-200 m high hanging pillars between the backfills, as only the bottom and southern contacts of profile 5 were mined at the time (Figure 5). A similar situation was achieved on profile 3. Mining in the central orebody profiles proceeded more slowly.

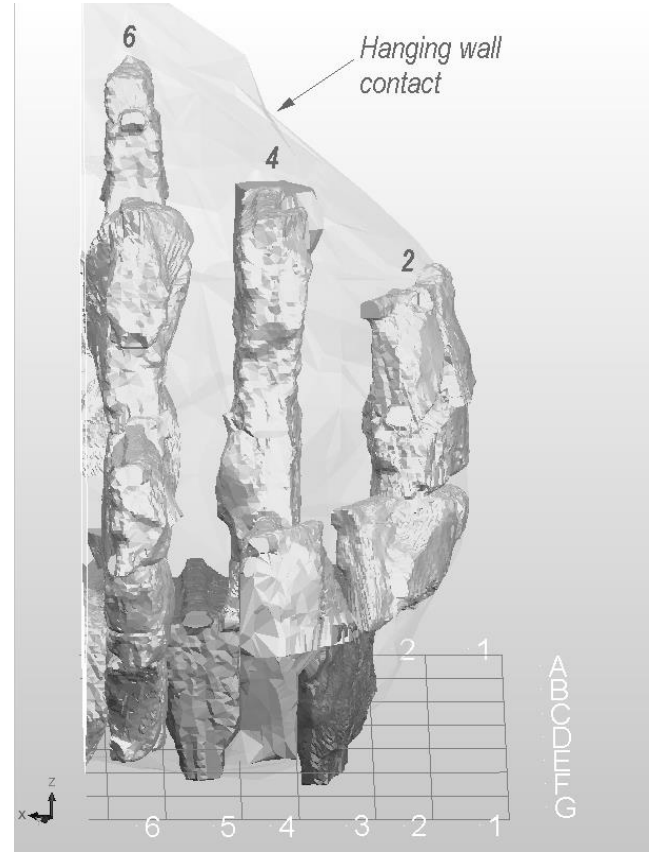

Figure 5 Mined out in profiles 2-6 at the end of year 2008, showing the hanging pillars which have been left between the backfilled primary stopes in profiles 2, 4 and 


\section{Only the bottom contact of the secondary profiles 3 and 5 have been mined. View looking from the north}

During the first half of the mine life, most primaries were mined with a sublevel and $50 \mathrm{~m}$ stope height. Large stopes with tonnages of $>100,000 \mathrm{t}$ were common, some concurrently in production on the opposite sides of a single secondary pillar. Pillar yield was not evident in all areas during the primary stoping (Brusila \& Hakala 2001). However, during high primary stoping, stope walls commonly started to peel off with seismic events and sometimes significant rockbursting occurring. Mined out stopes became barrel-shaped, whereas pillars in between thinned to hour-glass form (Figure 5). Seismicity was strongly mining-induced, but also affected some infrastructure close to the mining area. For example, one of the two orepasses suffered stress-related caving.

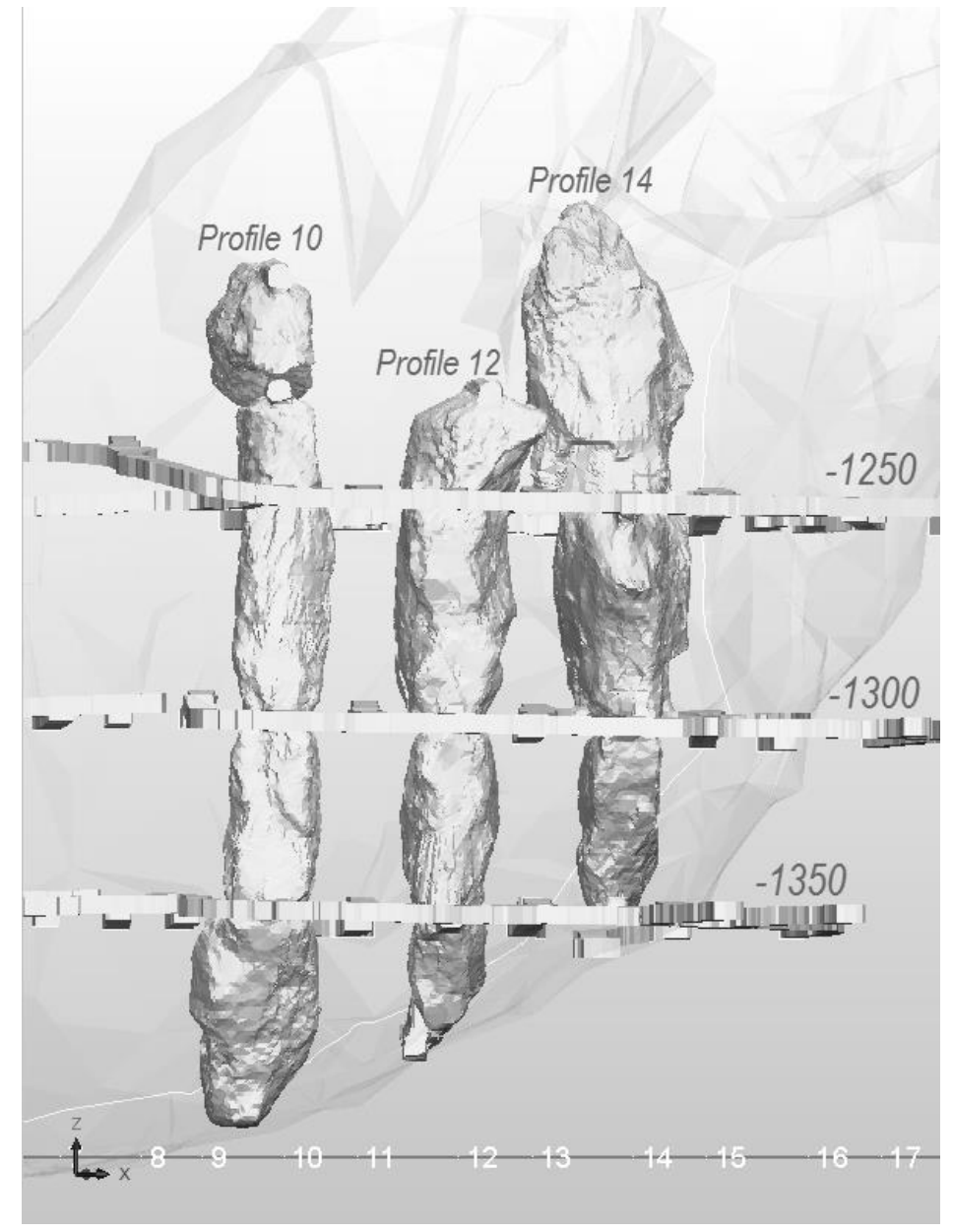

Figure 6 Most profiles 10,12 and 14 primary stopes against the southern wall rock contact, mined $50 \mathrm{~m}$ high, have caved to barrel shapes, leaving only thin pillars in between. The figure shows the scanned surveys of the primary stopes only. Looking from the south

\subsection{Secondary stoping}

Extraction of the first secondaries succeeded without any real stress-related problems, suggesting proper pillar yielding. The largest secondary stopes remained in production for around 12 months and produced about 250,000 t of ore. Some seismicity and subsequent damage was often observed at the end of stope life if stoping approached wall contact. Mining-induced seismic events were then located in the wall rock.

Secondaries in the hour-glass formed pillars in southern and western parts of the orebody were distinctly more fractured and blocky than the primaries. Some showed stope-wide oreblock slip along fractures, 
some of which were horizontal. Stope shoulders were especially susceptible to loose blocks, which resulted in a few serious near-misses. Seismicity was almost absent in the pillars during their mining.

While seismicity during the early years of mining had concentrated in the stope vicinities, clusters of seismic events now started to scatter around the orebody too. A notable change was the emergence of seismic cluster at the western hangingwall during 2009. The area is distant from all stoping and lacks access drives.

\subsection{Subsidence on contact zone}

During 2009, suspicions of slow subsidence of orebody along the wall rock contact arose. Slight downdip movement was first observed visually along the schistosity surfaces of the wall rock immediately outside the contact, at a secondary profile development in the profile 7 hanging pillar on level $-1,275$. The first extensometer was subsequently installed in a downhole drilled through the contact in the same development. During the first six months of operation, the extensometer showed $20 \mathrm{~mm}$ subsidence of the massive sulphide along a detachment line/lines parallel to the orebody contact (Figure 7). After the next 12 months the indicated movement was already $100 \mathrm{~mm}$ and by then, slip was observed in several places, not only in development roofs but also as floor drop in many oredrives at the immediate contact zone. In three years' time the largest downward slip had reached up to 2-2.5 $\mathrm{m}$ in profile 5 hanging pillar. The sinking has been observed in all profiles both north and south sides of the orebody and also in the middle part, but it is not consistent throughout; some profiles showing less downdip movement than others. Wall rock schistosity surfaces are acting as detachment surfaces (Figure 8).

Displacement vs Date/Time - 1275-EX-7 -1275 Level 7A6P

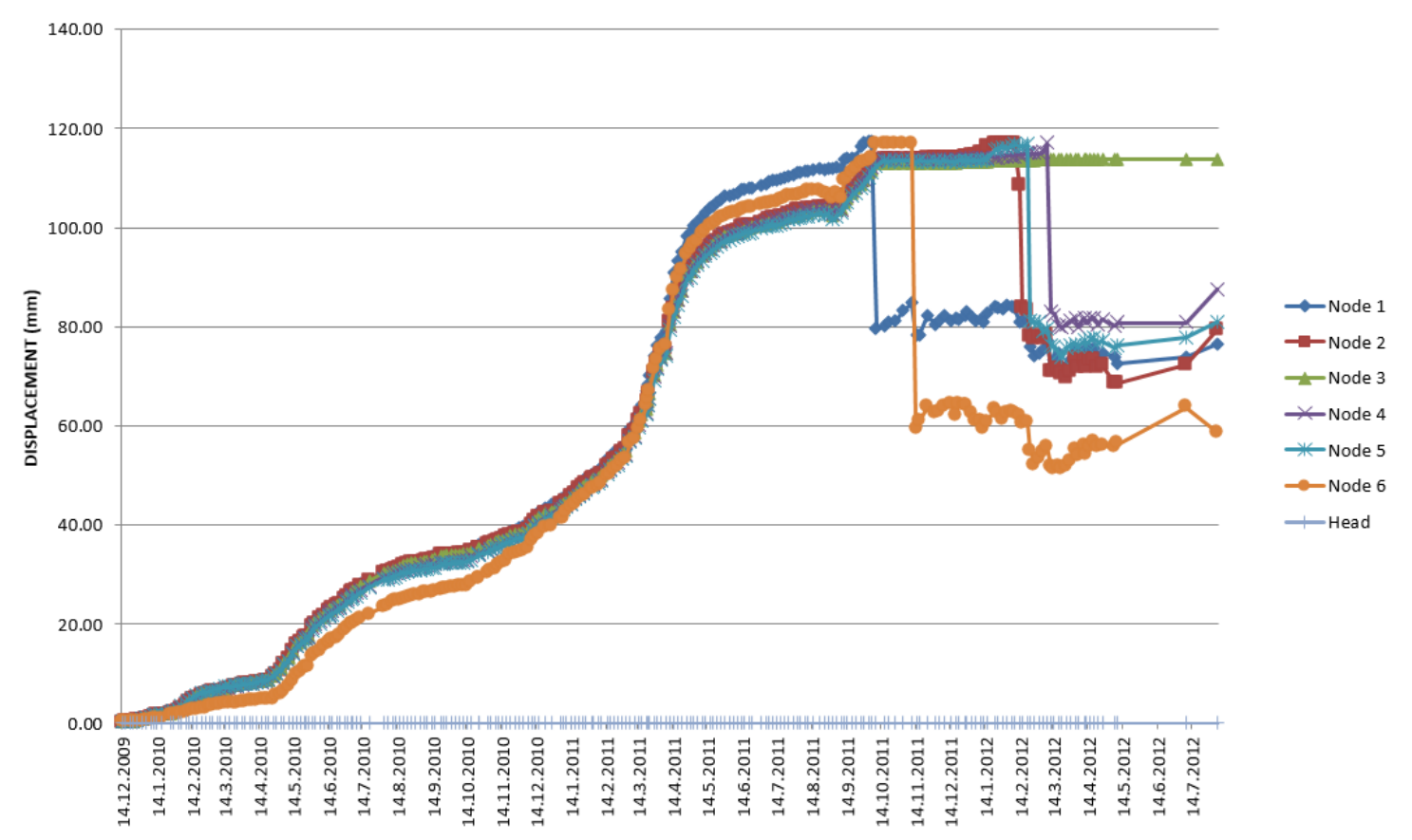

Figure 7 Data from the first extensometer installed on $-1,275$ level through the contact zone to monitor the subsidence 


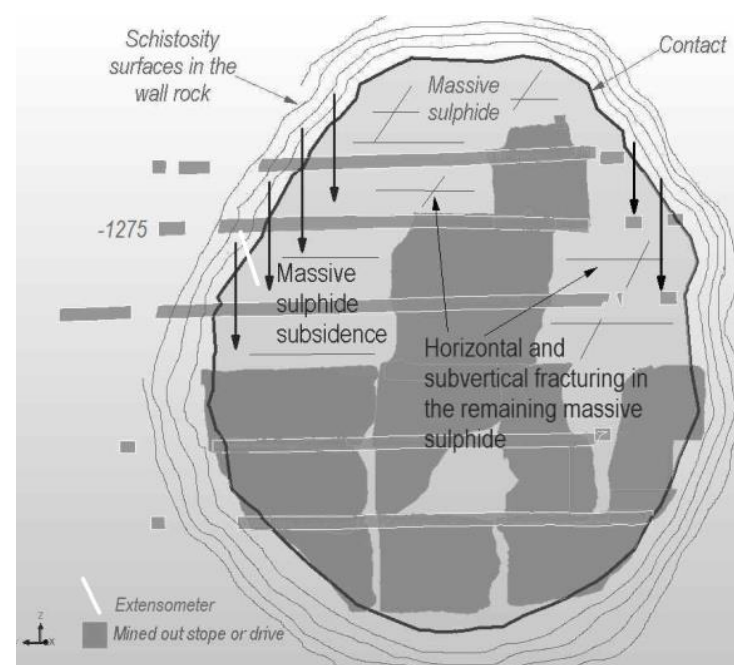

(a)

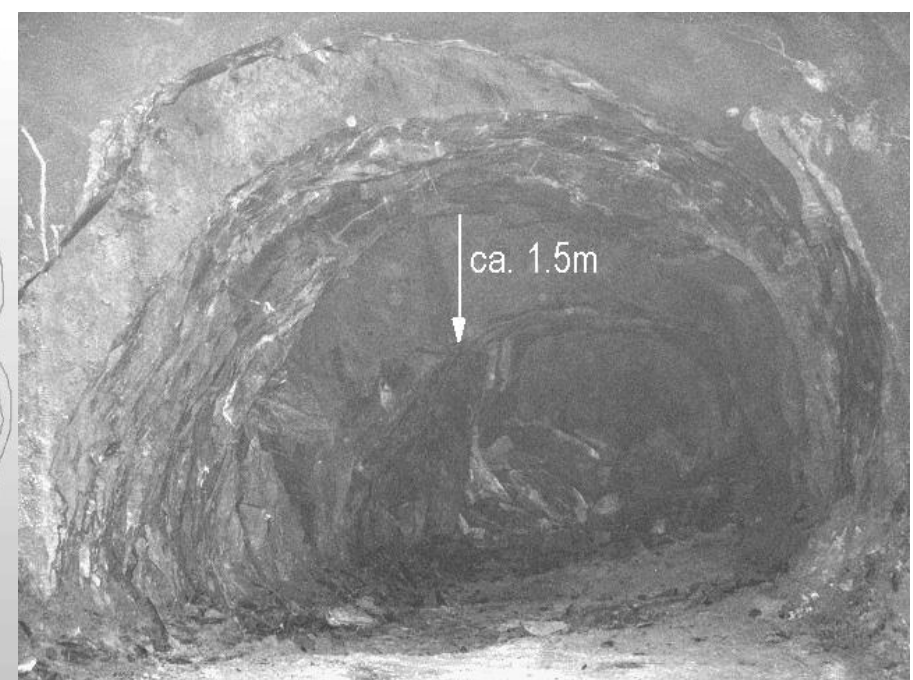

(b)

Figure 8 Schematic northwest-southeast cross-section along primary profile 6 (a), illustrating the wall rock schistosity surfaces tightly following the dip of the massive sulphide contact. As mining the primaries proceeded, the schistosity surfaces have detached and allow downward movement of the remaining fractured oreblocks against the backfill below. Photo taken from level -1,275 in the same profile (b) shows the downdip subsidence of oredrive at the contact zone

\section{$4 \quad$ Rock mechanical simulations and design}

The stress modelling work for the Pyhäsalmi deep mine can be divided to four phases based on the function: feasibility study (1998-1999), first primary stoping phase (2000-2001), early production phase (2004-2009) and late production phases (2010 to present). The major objectives of the feasibility study phase was to do rock mechanical classification for the orebody, estimate maximum unsupported and supportable stope sizes and the amount of cable bolt support needed, find safe locations for main level facilities, estimate the amount of rock support for incline as well as for level accesses and finally estimate the size of secondary stopes so that they work as yielding pillars and limit the concentrated stresses. Practically no rock mass quality or stress measurement data was available and intact rock strength and deformability data was mainly from the previously mined upper parts (Hakala et al. 1998; Luukkonen \& Hakala 1998). The description of the feasibility study phase numerical modelling is beyond the scope of this paper.

\subsection{Primary stoping phase modelling}

As extraction of the deep orebody started, more rock mass quality data was collected, strength of wall rock was tested and several in situ stress measurement were conducted at 1,125 level. The stress measurements indicated 65-68 MPa horizontal compression (Ledger 1999), setting a need to update the feasibility study. This work was concentrated on three aspects:

1. Safe location for mine infrastructure.

2. Stoping sequences.

3. Dimensioning of the secondary stope width (Hakala et al. 1999).

After this study, it was decided that stopes were to be oriented along the mining grid at angle of about $30^{\circ}$ to the maximum horizontal stress, the sublevel spacing was set to $25 \mathrm{~m}$ and the average primary stope size was $\mathrm{W}=18 \mathrm{~m}, \mathrm{~L}=25 \mathrm{~m}$ and $\mathrm{H}=50 \mathrm{~m}$. The width of secondary stoping was set to about $25 \mathrm{~m}$. After this 
phase, there was a clear need to repeat the stress measurements on $-1,400$ level and monitor the first stopes.

In the first primary stoping phase modelling local 3D elastic/plastic models were done for $-1,100$ and $-1,200$ levels. These models included two primary stopes and a secondary stope pillar between those covering two sublevels. The outcome of these models was that monitoring is needed to get more realistic estimates of the in situ and post failure strength of the rock. An extensometer was installed on -1,225 level to monitor pillar between two primary stopes. Back analyses indicated that the measured response was mainly elastic but yield was possible. The rock mass quality turned out to be clearly better than expected, GSI 93, and thereby the strength was greater as well. (Brusila \& Hakala 2001) At this time six in situ stress measurements were carried out on levels $-1,325-1,375$. These measurements were not very successful but the three best ones indicated very high horizontal in situ compression ranging from 56-98 $\mathrm{MPa}$ (Mononen 2000). After this, a new monitoring system was designed for the first primary stopes at the deepest levels; 1,410-1,375 including several extensometers and CSIRO-HI cells. Locations and primary predictions were based on elastic 3D BEM simulation to get the highest displacements and stress changes (Hakala 2001). At this time the owner of the mine changed, the monitoring was done but the results were never back analysed.

\subsection{First life-of-mine modelling}

The first LOM modelling was started in 2004. This DEM model features continuous isotropic elastic/perfectly plastic material model for both ore and waste rock. The first analyses results were compared with microseismic monitoring results, indicating that seismic activity correlates generally with simulated yield, but there were several locations were no seismicity was measured, although the model showed massive yield or vice versa. Other findings were that narrow secondary pillars are yielding at least partially, but wider pillars could be very highly stressed (Figure 9). Further, there will remain large yielded and loose rock volumes in uneconomic parts of the massive pyrite, i.e. inside the orebody which will load the remaining pillars and backfilled stopes (Sahala \& Antikainen 2005). The LOM simulation was updated in 2009. Results concerning the secondary pillars were similar with the previous study. In addition, it was noted that the horizontal pillar between levels $-1,250$ to $-1,275$ will first be highly stressed but will then yield with the stress state when excavated being lower than the in situ stress. Also vertical pillars at the bottom supporting the uneconomic central part of the pyrite will be very highly stressed (Antikainen 2009). 


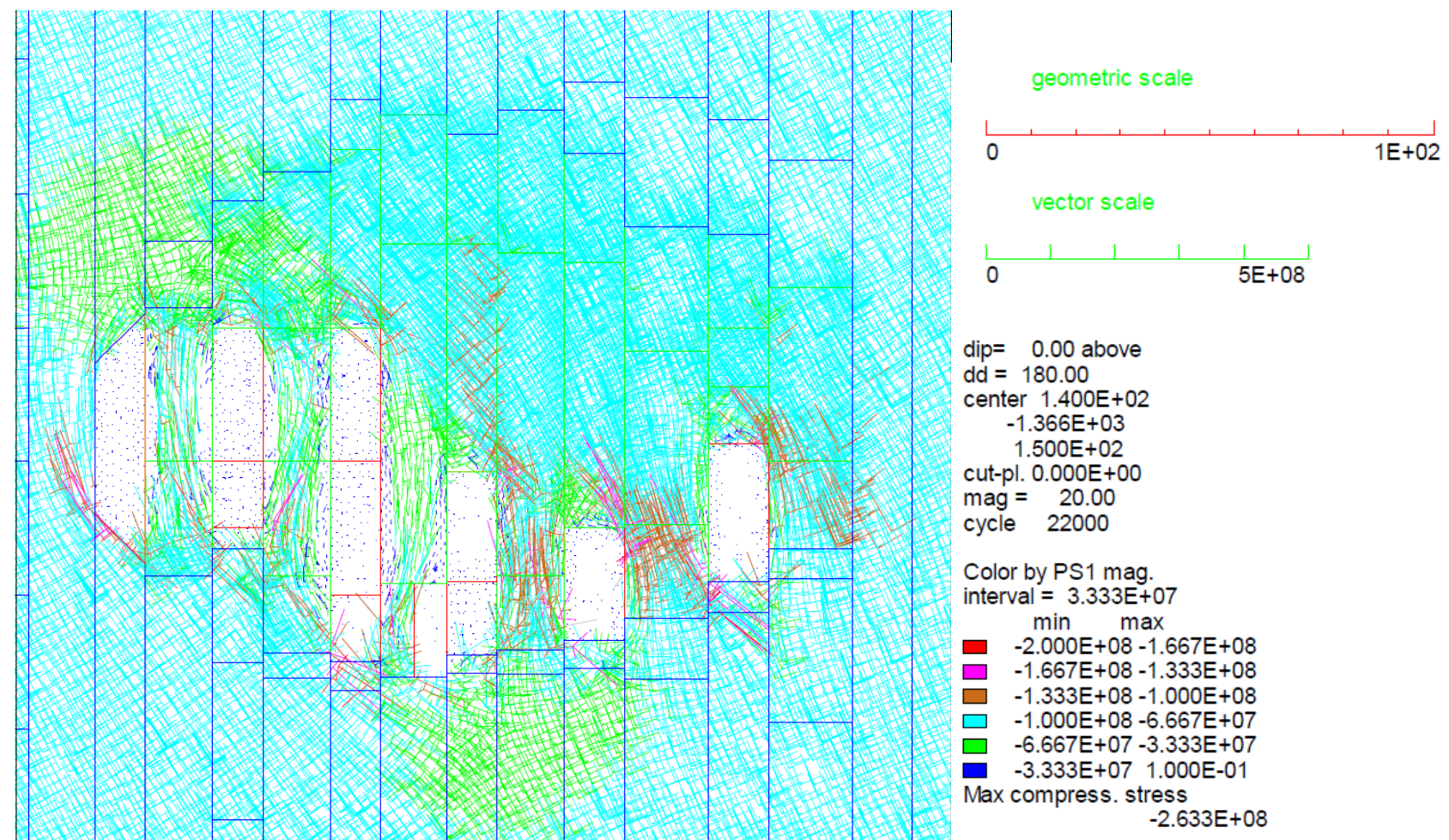

Figure 9 Principal stress tensors after primary stoping phase on level $-1,336$

\subsection{Late production phase modelling}

The latest simulation phase was initiated in 2010, roughly in the middle of the production of the new mine. The major objectives were the stability of secondary pillars and the uneconomical central part of the pyrite, the risk of violent dynamic stress release, the risk level of vital connections and the behaviour of horizontal pillar. This work was started by calibrating the material parameters of the previous LOM model to fit with seismic monitoring results. This calibration ended up using brittle strength model used for both pyrite and waste rock. In the brittle strength model, the initial strength is practically cohesive and the cohesion is lost and friction mobilised with increasing plastic strain, i.e. yield. Further, low shear strength contact was assumed between pyrite and waste rock.

The major finding was that the uneconomic central part of the massive pyrite will be de-stressed and start to sink between 2014 and 2016. The actual large scale oreblock subsidence was noticed at the same time with these simulations. Other findings were that monitored seismicity has the best correlation with plastic shear strain or high stress front. Correlation between stope excavation and measured seismicity is at best described as moderate. When the total excavated volume in certain area increases, seismicity could be observed 4-8 months after the last excavation. It was noted also that the stope grid based modelling approach may have resulted in geometric constrain for the remaining parts of the pyrite and contact (Hakala et al. 2010; Hakala et al. 2011).

Guided by these ideas, the 3D numerical model (3DEC) was rebuilt based on geological domains and orientation of foliation which follows the pyrite contact, which was modelled as a weakness plane by applying strength anisotropy. The initial and residual strength parameters of ore and waste rock were then calibrated so that initiation and magnitude of the subsidence matched the observations, which resulted in a $30 \%$ reduction to the initially estimated strength. Key findings from this simulation were that highly stressed future stopes exist until 2012 , especially above the $-1,250$ level. After that, mining induced stresses through the pyrite body decrease quickly which correlates with the initiation of subsidence of the roof contact. After 2014 most of the stresses in the central pyrite orebody have been relaxed. This relaxation initiates subsidence of large rock volumes inside the pyrite contact and above the roof contact (Figure 10). It was found that alternative LOM stoping sequences or leaving a high number of stopes unexcavated will 
not reduce the roof contact displacements remarkably, when inspecting the modelling results from years 2016 and 2019 (Lamberg et al. 2013).

In all simulated cases the ramp, technical facilities, orepasses and raises are not noticeably affected by mining. Consequently the original LOM is suggested in regards to current knowledge, but the major concern is the true nature of the subsidence; in calculations unexcavated parts of the pyrite and the waste rock above roof contact displace smoothly, but in reality it could be locked and subsequently fail violently (Lamberg et al. 2013).
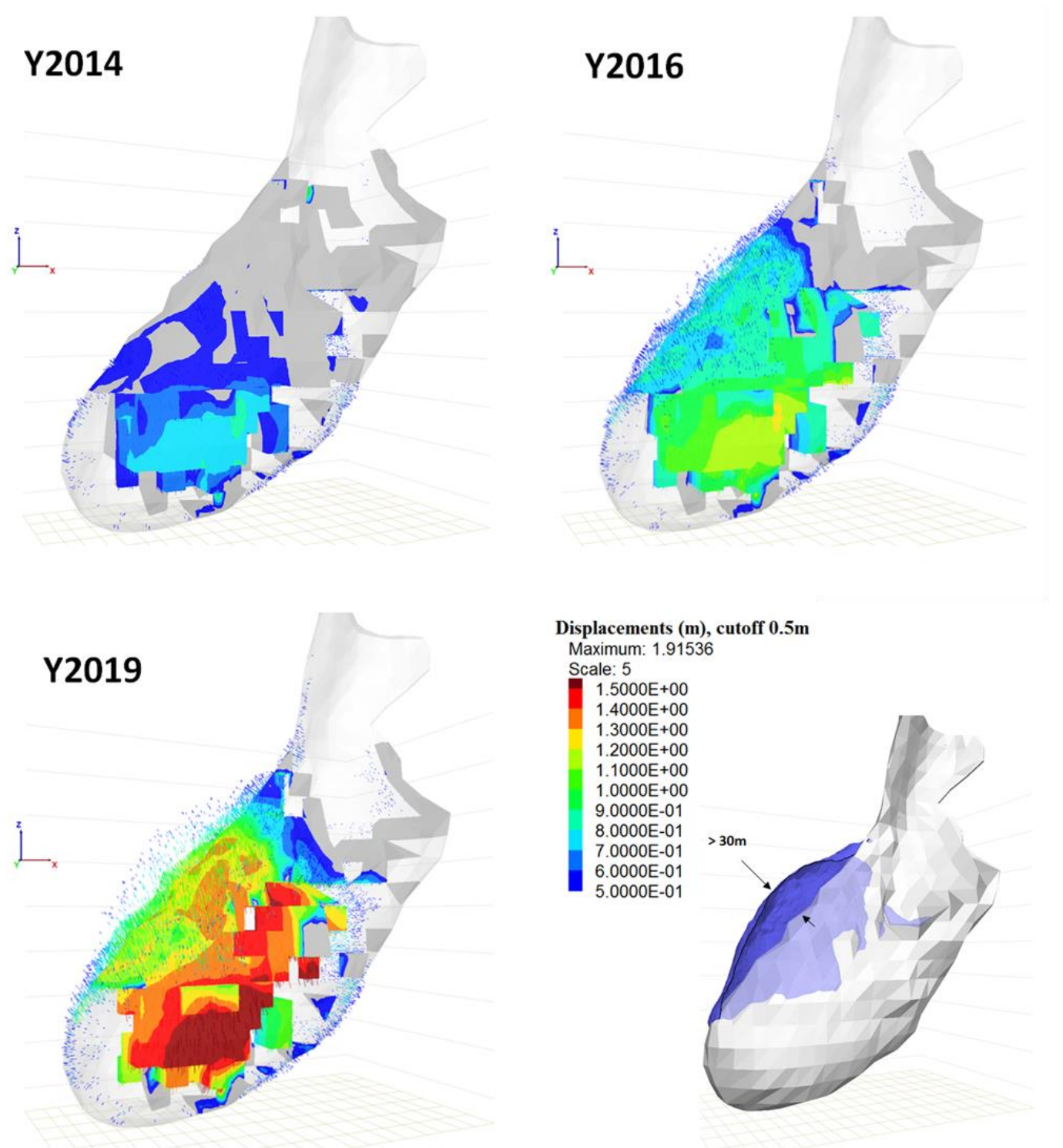

\section{Figure 10 Displacement vectors in the roof contact and subsidence contours for unexcavated pyrite. The extent of $0.5 \mathrm{~m}$ modelled hangingwall contact displacement in 2019 is shown in the lower right}

\section{$5 \quad$ Rock mechanical monitoring}

Implementation of monitoring systems is an important part of mining especially in high stress conditions. These systems measure the response of the rock mass to the formation of the excavation and may also be used to calibrate geotechnical models. The main aim of any rock mechanical monitoring is to provide a safe working environment for mine personnel. 
Rock mechanical monitoring at Pyhäsalmi Mine has changed over the years as the mining conditions have changed. Originally yielding pillars were designed to be monitored by extensometers and three dimensional stress gauges used for back analysis. After the orebody subsidence on contact was identified, extensometers have also been used for ore and waste rock contact displacement. In addition, fixed point surveys were also introduced to monitor subsidence on the contact. A microseismic system was installed in 2002 to identify and locate yielding. Visual damage mapping has been used to recognise rock fall and other hazards and it has also been used as a back analysis tool for the other monitoring methods.

It is important to appreciate that monitoring without purpose is without value. All collected data has to be applied to the interpretation or solution of actual problems.

\subsection{Seismic monitoring}

Due to the high stress conditions encountered during the development of the new orebody at a depth of $1,000 \mathrm{~m}$ below surface, a decision was made to install a microseismic system in the Pyhäsalmi. In-mine microseismic monitoring system was installed during 2002 and it has been upgraded couple of times since then.

For geotechnical purposes, the monitoring of seismicity provides an opportunity to calibrate the relationship between the stress environment and the rock mass strength, from which it should be used to adapt geotechnical designs and mining sequences. The greatest benefit to the mining operation is if seismic monitoring is implemented proactively so that designs and mining layouts can be adjusted before seismicity becomes disruptive to the mining operation.

At the early stage of mining the new orebody below at depth of $1,000 \mathrm{~m}$, seismicity occurred mainly inside the orebody and specially in yielding pillars between primary stopes. Since the subsidence on the contact started in 2009, seismicity has moved outside the orebody due to the stress redistribution. During the last two years, seismicity has moved even further from the contact zone (Figure 11). This has happened because the contact zone areas near the orebody have been permanently damaged and relaxed conditions do not create seismic activity. 


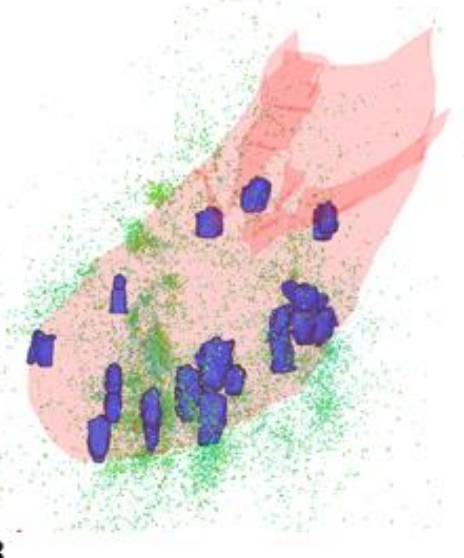

2008

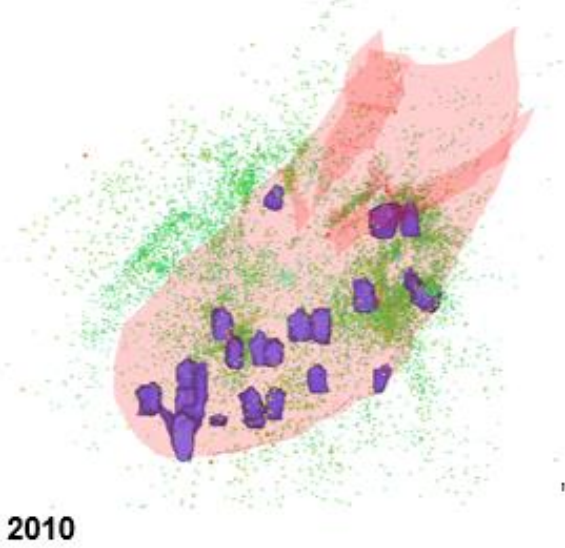

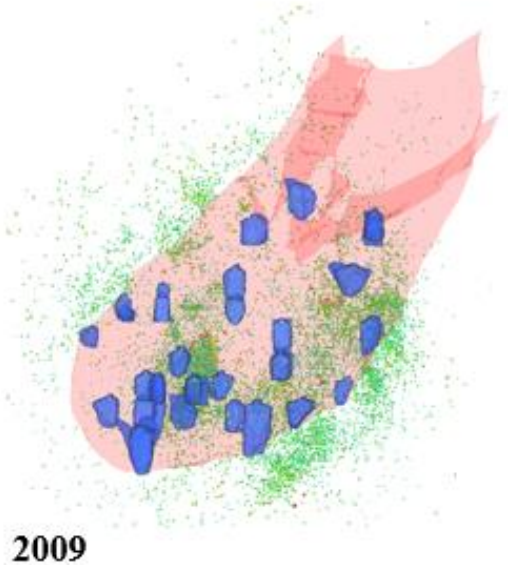

Local Magnitude

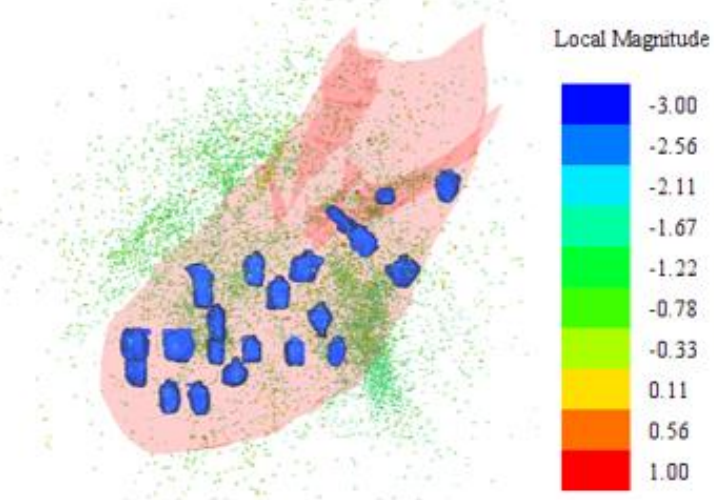

2011

\section{Figure 11 Seismic events - changes in seismicity over the years}

The latest phase of rock mechanical modelling also indicates that most of the areas close to the contact zone are in a residual state. The strength of the rock in those areas is almost totally frictional. The high stress front is related to yield (permanent damage), where this front is the source of the majority of the seismic events.

Increased seismicity around the orebody has increased damage and causes additional rehabilitation costs in level and stope access drives near the orebody.

\subsection{Extensometers}

Extensometers are used for monitoring the displacement of anchors relative to the extensometer head. Dependent on the installation configuration, the first or last anchors are assumed to be located at a stable point with displacements measured relative to one of these. Typically they are implemented where a structural instability has been identified and extensometer anchors can target the failure plane.

At Pyhäsalmi Mine the first extensometers were installed to monitor the excavation response and the pillar yielding that was interpreted to occur in secondary stopes before excavation. At this stage Pyhäsalmi Mine didn't have a microseismic system to identify and locate yielding. After the subsidence on contact was observed and mining conditions changed, extensometers have been used for subsidence monitoring as well as critical areas such as above active stopes. The typical extensometer used at Pyhäsalmi Mine has been $15 \mathrm{~m}$ long multi-point borehole extensometer with six anchor points.

Reading from extensometers are collected manually twice per week and results are analysed in rock mechanical weekly reports. In the cases of sudden increase in displacement rates, production personnel underground are informed. 
An example of displacement rates from an extensometer at the contact zone subsidence are shown in Figure 7. Increased displacement rates correlate well with increased seismicity in monitored areas. The installed extensometer had a maximum displacement of $120 \mathrm{~mm}$.

Wireless monitoring of extensometers and Smartcables have been trialled in three different levels since September 2012. This allows us to monitor critical stopes and risk areas in real time with no manual labour required and alarms set up when required (Figure 12).

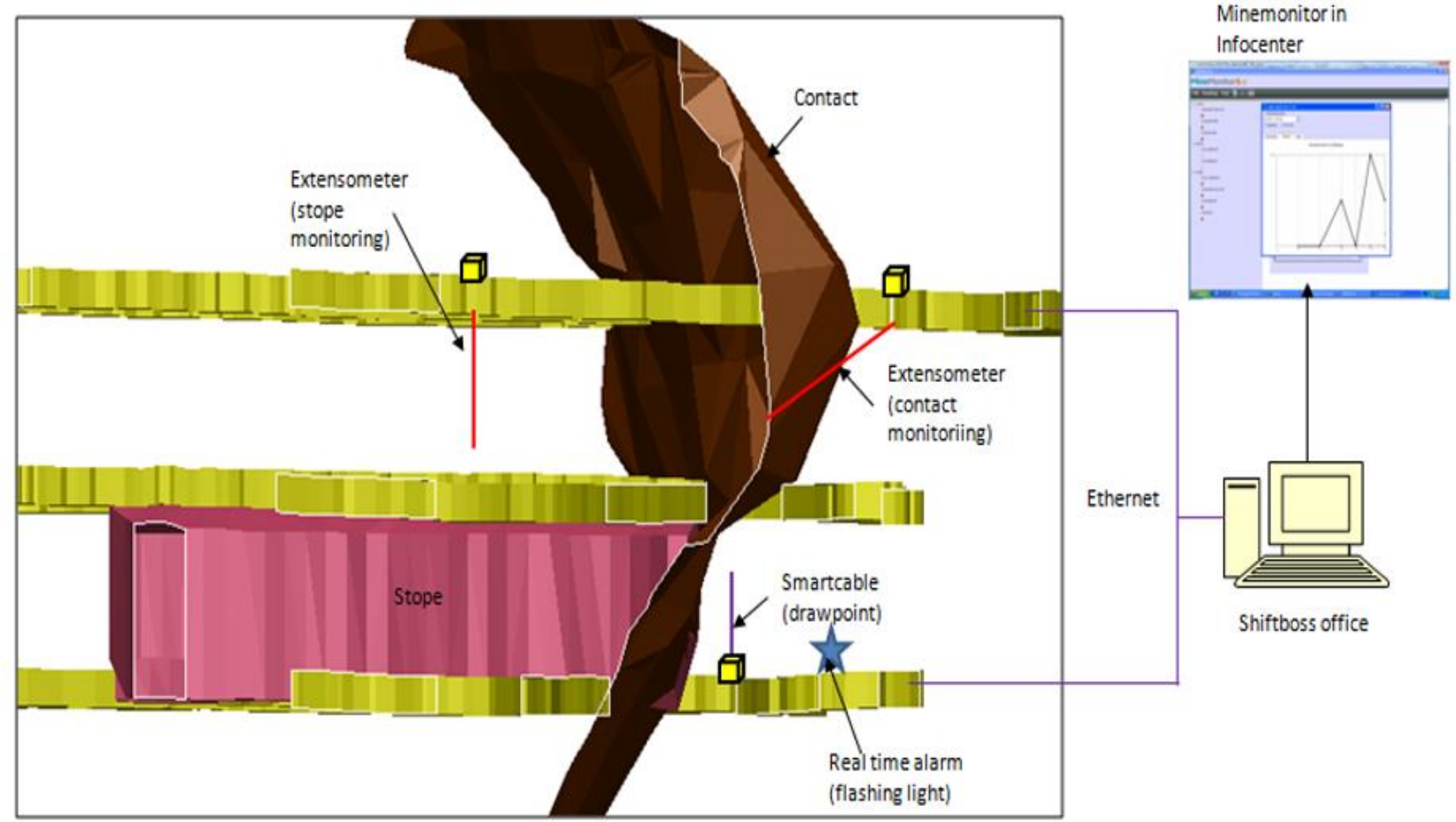

\section{Figure 12 Extensometer/smartcables - typical instrumentation setup with additional wireless system}

\subsection{Fixed survey points}

Fixed survey points are normal underground survey points/stations that are used for subsidence on contact monitoring. The same survey points are surveyed regularly and the amount of displacements recorded.

\subsubsection{Displacement block model}

A displacement block model was created to make it easier to visualise subsidence in contact and the amount of displacement in different areas. The block model was first created using fixed survey point data and maximum displacement in all installed contact extensometers. To increase the accuracy and area coverage, development backs were surveyed across the contacts in all levels where there is access available. The maximum differences between points on both sides of the contact $w$ then added into the block model.

The search area around the blocks was changed to get the best possible correlation between the block model and observed displacement in contact areas on different levels. In Figure 13, the search area used was $100 \mathrm{~m}$ around the surveyed points and displacement data is presented in centimetres. The block model is easy and quick to update monthly using new survey data. Correlation between visual observations and the block model is good and it can be used to identify geotechnical risk areas as well as in ground support scheduling and planning. 


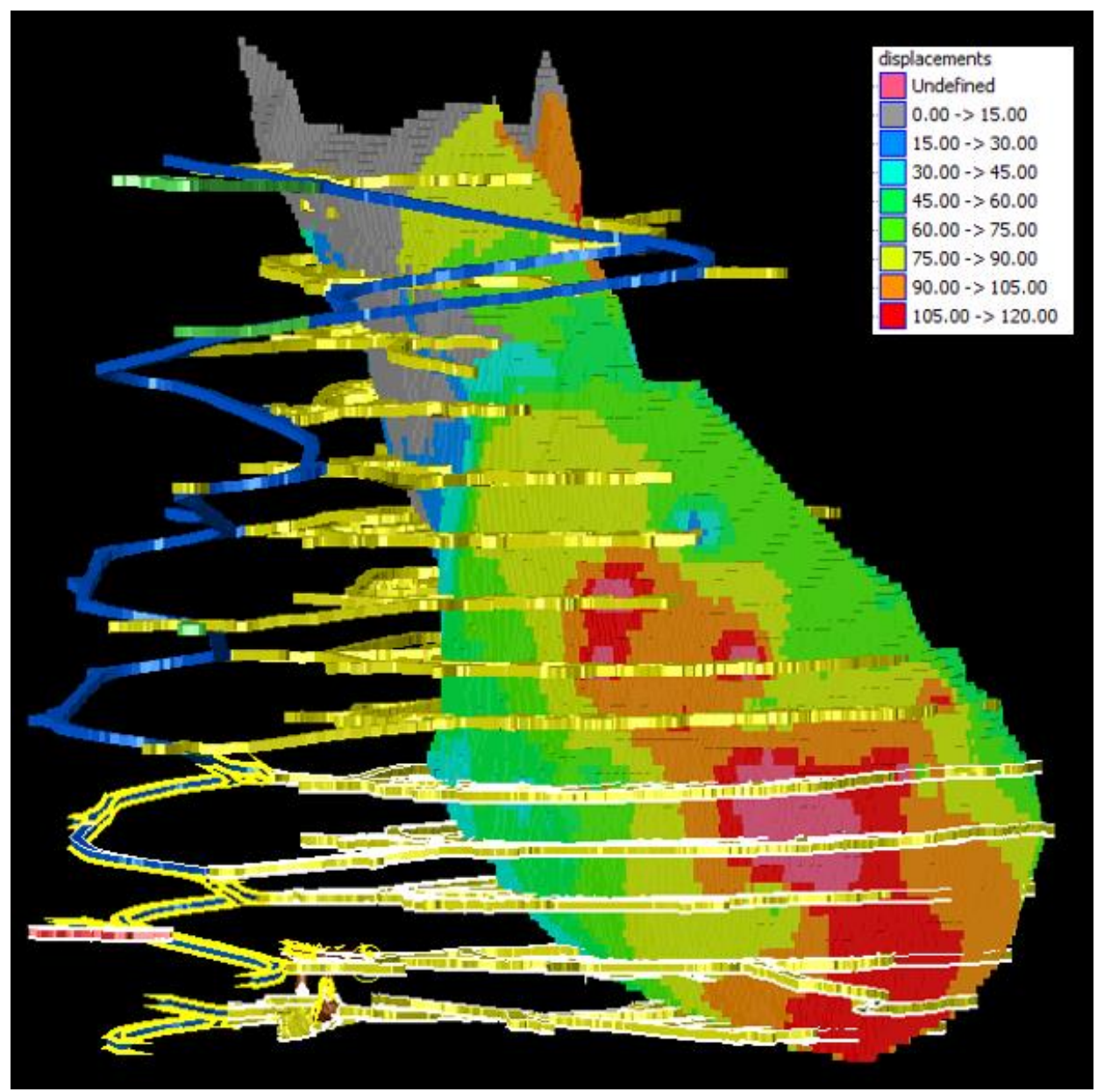

Figure 13 Displacement block model

\subsection{Damage mapping}

The proactive inspections of all excavations, looking for damage, rockfalls and other hazards, is every individual's duty of care and integral part of everyday procedures for accessing and carrying out their work-related tasks in the workplace.

These observations must be embedded into a system, which will ensure that the entire workforce is well trained to recognise rockfall and other damages underground.

At Pyhäsalmi Mine regular damage follow-ups and recording are done daily to relate seismic events and subsidence on contact to rock mass condition. Damage mapping information is used for ground support scheduling and designs and also for back analysis for seismic data and rock mechanical modelling results.

\section{$6 \quad$ Adjusting mine planning and stoping to changing conditions}

Competent ground conditions, with sparse fracturing and massive rock, enabled $50 \mathrm{~m}$ high primary and even secondary stopes in the early mine life despite the high stress affecting in the mining area. However, rock mass loosening due to mining-induced fracturing and further block movements in the orebody created a need to rethink the mine planning criteria again. The following sections aim to illustrate the changes that have been adopted into the mine planning and stoping to best adjust to changing conditions.

\subsection{Stoping dimensions}

Doubts on proper yielding in the pillars in the primary stoping made way to very large stope size used during the first half of the mine life. A height of $50 \mathrm{~m}$ and length of $40-60 \mathrm{~m}$ was normal, as radio-remote controlled mucking was used. However, prolonged mucking periods combined with rock bursting, onion 
skinning and caving of stope walls in the primaries, as well as growing experience in stoping the secondary stopes pushed the stope dimensions towards only $25 \mathrm{~m}$ high. As it became evident that pillars were indeed yielding, despite the occasional lack of clear seismicity within them, the decision was evident and only speeded up by backfill stability problems in the $50 \mathrm{~m}$ high mined out voids. Today, only $25 \mathrm{~m}$ high stopes are excavated. Tele-remote mucking of the non-entry stopes enables mining units as long as 70-80 m, although shorter ones are preferred for stability reasons.

\subsection{Drilling patterns and backfilling}

Strict primary-secondary stoping sequence originally applied required consolidating backfill only in the primary stopes. During the first half of the mine life, the secondaries were invariably left with rockfill only (except those locating over known crown-pillars).

Tight rockfill under stope shoulders proved difficult. A typical downhole stope drilling pattern left a shoulder angle larger than $45^{\circ}$, and tight rockfill into an empty space formed under the shoulder was difficult. Stopes were simply left with 1.5-2 m void under the shoulders. This, combined with compaction of rockfill, allowed tensional fracturing and downward movement of the massive sulphide especially in the secondary profiles.

After first observing the contact detachment and block movements of the ore, old rockfilled stopes have been consolidated one by one, either through cemented hydraulic fill (CHF) leakages in the fractures or intentionally. The need to control oreblock sinking also required measures for better support under the stope shoulders. Firstly, the stope drilling pattern was changed to achieve a steeper shoulder angle and improved backfilling to the stope edges. Secondly, all stopes are now consolidated. Thirdly, the level of CHF in the stope can be raised to cover the shoulders and provide extra support in the areas where oreblock subsidence is problematic. And fourthly, efforts to keep the CHF from leaking out of stopes into fracturing rock mass have been made using both cement and urethane grouts as well as additives into the CHF.

\subsection{Ground support}

During the early years of deep mining, competent conditions especially in the massive sulphide required little support, and numerous oredrives were developed using only surface support of 3-5 cm shotcrete layer. Twin strand 6-9 m cable bolts were then installed prior to stoping. Kiruna bolts (cement grouted point-anchored rebars with faceplates, length $2.1 \mathrm{~m}$ ) were used in wall rock access drives together with fibre reinforced shotcrete. The wall rock support was therefore relatively stiff considering the burst-prone ground.

While stoping proceeded, cable bolting and occasional mesh was used to rehabilitate the access drives especially in the large cross-cuts. On levels with continuous production activities, proper rehabilitation was strenuous and often overdue. After contact zone detachment and slip activated, ground conditions in access and oredrives in the vicinity deteriorated faster than rehabilitation was able to follow.

Today, mesh is invariably used in primary support and rehabilitation of the access drives. All cross-cuts and contact zones are cable bolted. Kiruna bolting with fibrecrete is used for primary support in oredrives, with occasional meshing in the most fractured locations. Cable bolting patterns have been reviewed for both primary and secondary stopes, and are always designed individually for each stope. Tests for the best suitable fibre for shotcreting are currently being made.

\subsection{Sequencing in LOM}

With the present reserves and stope sizing, approximately 120 stopes remain to be mined. Stope sequencing has been gradually moving from the strict primary-secondary sequence to more variable models that apply horizontal retreat where possible. The stoping order must be determined by profile and stope by stope in those areas where oreblocks are moving. Two-profile wide spans, long mucking periods and several stopes concurrently in production against the wall rock contact must be avoided. 
The former mining sequence, which preferred high stopes and heavy extraction in the primary profiles, has left high pillars for secondary mining. Oreblocks in the hanging pillars are sinking at the highest rates and show largest downdip slips. Mining sequence and stope sizing in the pillars must be carefully thought to avoid blocks that remain between backfills and detached contact.

\section{Conclusion}

Rock mass response in Pyhäsalmi deep orebody has undergone a material change during 13 years of mining. Competent massive sulphide and high stress rockburst-prone ground, with distinct seismicity located around active stopes, has turned into fractured and loose rock mass susceptible to block movements caused by detachment of schistosity surfaces at the wall rock contact. Seismic event locations have moved to the outskirts of production areas and even further to affect the mine infrastructure. Mine production has been compelled to adjust to the changes by modifications in stope sequencing, design and backfilling.

Ground support conventions have also evolved from the need of using only surface support of rockbolts and shotcrete with cable bolting in stopes, to extensive use of mesh and fibre reinforced shotcrete. Constant rehabilitation is required in the contacts zones of massive sulphide, where the largest downdip subsidence of oreblocks is about $2 \mathrm{~m}$. A history of numerical stress modelling since the start of deep extraction has produced a model that corresponds to the observed rock mass behaviour reasonably well. Despite some deficiencies in timing of relaxation it can well be expected to predict conditions for the remaining LOM. It also shows that the understanding a mine's rock mechanics environment is a learning curve.

Another question is how the continuing de-stressing will be managed in the future. Successful mining in these changing conditions has required changes in stoping practices, but also new ways of thinking from all members of the production team - and will probably continue to do so.

\section{References}

Antikainen, J 2009, Modelling of stoping for Pyhäsalmi Mine, Calculation memo, Helsinki University of Technology, Helsinki.

Brusila, J \& Hakala, M 2001, 'Yielding pillar design at Pyhäsalmi new mine', in P Särkkä \& P Eloranta (eds), Proceedings of the ISRM Regional Symposium: Eurock 2001, Balkema, Netherlands.

Hakala, M, Somervuori, P \& Syrjänen, P 1998, Outokumpu Mining Oy, Pyhäsalmen kaivos: Rock mechanics study for deep extension between levels 1050...1400, (in Finnish), Gridpoint Finland Oy, Helsinki.

Hakala, M, Somervuori, P \& Syrjänen, P 1999, Outokumpu Mining Oy, Pyhäsalmen kaivos: Rock mechanics study for deep extension between levels 1050...1400 - Part II, (in Finnish), Gridpoint Finland Oy, Helsinki.

Hakala, M 2001, Outokumpu Mining Oy - Pyhäsalmi New Mine: Study of secondary stresses around deepest stopes between levels 1325 - 1410 and design of monitoring system, Gridpoint Finland Oy, Helsinki.

Hakala, M, Kuula, H, Matinlassi, M, Somervuori, P, Syrjänen, P \& Tolppanen, P 2002, Analyses of Tunnel Stress Failures at Pyhäsalmi Mine, Posiva Working Report 2002-28, Posiva Oy, Helsinki.

Hakala, M, Kuula, H, Merjama, S, Somervuori, P \& Antikainen, J 2010, Rock Mechanical Study 2010 - Phase 1 for Pyhäsalmi Mine Oy, KMS Hakala Oy, Helsinki.

Hakala, M, Kuula, H, Merjama, S, Somervuori, P \& Antikainen, J 2011, Rock Mechanical Study 2010 - Phase 2 for Pyhäsalmi Mine Oy, KMS Hakala Oy, Helsinki.

Lamberg, M, Kuula, H \& Hakala, M 2013, Life of Mine Rock Mechanical Simulation for Pyhäsalmi Mine Oy, Research Report, Pöyry Finland Oy, Helsinki.

Ledger, L 1999, Stress measurement in the 1125m level, Outokumpu Oy, Pyhäsalmi Mine, Rock Mechanics Technology Ltd., UK.

Luukkonen, K \& Hakala, M 1998, 'Pyhäsalmen kaivoksen syvämalmin hyödyntäminen' (in Finnish), Louhinta- ja kalliotekniikan päivät 19-20.22.1998, Hyvinkää, SML, RGY ja Suomen kalliomekaniikkatoimikunta, Helsinki.

Mononen, S 2000, Stress measurement with CSIRO-HI cell on levels 1325, 1350, 1375 at Pyhäsalmi (in Finnish), Helsinki University of Technology, Espoo.

Sahala, K 2011, 'Working under high pressure', in P Särkkä \& J Aho (eds), Rock - Sound of Countless Opportunities, Finnish Tunneling Association, Keuruu.

Sahala, K \& Antikainen, J 2005, Numerical Modelling and Microseismic Monitoring of Stoping at Pyhäsalmi (in Finnish), SGY Finnish Geotechnical Society and The Finnish National Group of ISRM, Helsinki. 